\title{
Symbolism of sacred and profane animals in the Quran
}

\author{
Simbol hewan suci dan profan dalam Quran
}

\author{
Anas Ahmadi \\ Department of Indonesian Language and Literature Education, Faculty of Language and Art, \\ Universitas Negeri Surabaya \\ Address: Jalan Raya Kampus Unesa, Lidah Wetan, Surabaya, East Java 60213 \\ E-mail: anasahmadi@unesa.ac.id
}

\begin{abstract}
The story of animal symbolism is associated with knowledge and wisdom. This is in order to be used as an example by humans as a valuable lesson. Humans can learn ethics from fables. In the modern view, the symbolism of animals in relation to the issue of eco-psychology has become a trending topic. This study aims to explore the symbolism of sacred and profane animals in the Quran through a hermeneutic-anthropological perspective. This study used a qualitative-descriptive method by describing the data narratively. The data analysis techniques used in this study are hybridization techniques. First, there is reciting the verses (hermeneuticalanthropological) in the Quran can be either universal or particular. Second, there is identifying the passages that relate to animals, whether real pets or unreal ones (symbolism). Third, there is the classification of the animals associated with the pattern of binary oppositions, and the Quran in the context of mytheme (unit of myths) and cheritheme (unit of the story). Fourth, there is the search for collective mediation functions for the community supporters who are in the Quran - mytheme and cheritheme animals. The findings of this study are that: 1) animal symbolism in the Quran appears in the form of either dyadic or triadic and 2) the symbolism of animals the Quran shows that animals in the Quran have a collective mediating function for the supporting community, i.e. a) animals as intermediaries towards holy people (through sacrifice); b) animals as medicine/human health; and c) animals as protectors. The conclusion of this study shows that animals in the Quran appear in both real and symbolic form.
\end{abstract}

Keywords: symbolism; sacred-profane; animals; Quran; anthropology

\begin{abstract}
Abstrak
Kisah simbolisme hewan dikaitkan dengan pengetahuan dan kebijaksanaan untuk digunakan sebagai contoh oleh manusia sebagai pelajaran yang berharga dan manusia dapat mempelajari etika kehidupan dongeng. Dalam pandangan modern, simbolisme hewan dalam kaitannya dengan masalah ekopsikologi menjadi topik yang sedang hangat. Penelitian ini bertujuan untuk mengeksplorasi simbolisme hewan suci dan profan dalam Al-Quran melalui perspektif hermeneutik-antropologis. Penelitian ini menggunakan metode kualitatifdeskriptif dengan mendeskripsikan data secara naratif. Teknik analisis data dalam penelitian ini menggunakan teknik hibridisasi. Pertama, membaca ayat-ayat (hermeneutis-antropologis) dalam Al-Quran dapat bersifat universal atau khusus. Kedua, mengidentifikasi bagian-bagian yang berhubungan dengan binatang, yaitu hewan peliharaan nyata atau yang tidak nyata (simbolisme). Ketiga, klasifikasi hewan dikaitkan dengan pola oposisi biner, Al-Quran dalam konteks mitos (unit mitos) dan cheritheme (unit cerita). Keempat, pencarian fungsi mediasi kolektif untuk pendukung komunitas, yang ada di dalam Al-Quran - binatang mitos dan cheriteme. Temuan penelitian ini, yaitu 1) simbolisme hewan dalam Al-Quran muncul dalam bentuk diadik atau triadik dan 2) simbolisme hewan Al-Quran menunjukkan bahwa hewan dalam Al-Quran memiliki fungsi mediasi kolektif untuk komunitas pendukung, yaitu a) hewan sebagai perantara menuju orang suci (melalui pengorbanan); b) hewan sebagai obat/kesehatan manusia; c) hewan sebagai pelindung. Simpulan dari penelitian ini menunjukkan bahwa hewan dalam Al-Quran muncul dalam bentuk nyata dan simbolis.
\end{abstract}

Kata kunci: simbolisme; sakral-profan; animals; Quran; antropologi

\section{Introduction}

The Quran is the holy book of Muslims. As a holy book, the Quran contains a wide range of science (Saeed 2006:1) of a high complexity (Rahman 2007:31) with highly scientific values of wisdom (Yahya 2003:17). Therefore, many clerics and scientists are interested in studying the Quran from the ontological, epistemological and axiological perspectives. There are different kinds of symbolism 
in the Quran, one of which is the symbolism of animals. In the classic view, a study of animals is called a bestiary. These became popular in the Middle Ages. The term 'bestiary' refers to the story of animals in the past, such as the unicorn, lion and dragon (Hassig 1995:1). The story of animal symbolism is associated with knowledge and wisdom in order for it to be used as an example by humans as a valuable lesson. Humans can learn ethics through the life of the fables. In the modern view, the symbolism of animals in relation to the issue of eco-psychology becomes a trending topic. The Quran is the holy book of Islam. This explains what is meant by bestiaries in past thoughts and it is talked about what is meant by the eco-psychology on modern thought which has now become a trending topic. The Quran presents nature as a whole, namely plants, the environment and animals. The empirical facts show that the Quran is the holy book that is relevant to humans' knowledge and even beyond their knowledge. The Qur'an provides a perfect picture of the universe and what is beyond the material in the universe in a rational manner so then it attracts the attention of both educated and uneducated people (Rahman 2007:36).

In relation to animals, this paper has described the symbolism of sacred and profane animals in the Quran. During this time, the study of the symbolism of animals is not a new one. Based on the author's observations, the research on animal symbolism is divided into two. First, there is the research done on animal symbolism in a general context. They consist of a) animals in the Bible (Worcester 2017), b) animals with Christian symbolism (Skrobonja et al. 2001), c) animal symbolism in the literature (Hassan \& Sayed Sadek 2015), d) the ratio of animal sacrifice in ancient Greek, Judaism and Christianity, from 100 BC to 200 AD (Petropoulou 2008), e) animals and religion and f) animals and folklore (Martinelli 2012) and animal classification (Kitchell 2013). Nowadays, animals and religions from interdisciplinary perspectives are starting to get busy. Schaefer (2015) talks about animals, religion and interdisciplinary approaches.

Second, there is research into animal symbolism in a specific context which is associated with the research/article on animals in the Quran. This covers 1) the animals in the world of Islamic societies and how these are associated with the animals in the Quran (Foltz 2006), 2) animals in the Quran (Birruni 2012, Bahjat 1982, Hidayat 2010, Dundes 2003) and 3) the filmed animals in the Quran, referring to a fable from the Quran as shown on MNC TV (Indonesia) in August-September 2012.

Research on animals in the Quran that has been done by Dundes (2003), Foltz (2006), Bahjat (1982), Hidayat (2010), Birruni (2012) and Tlili (2012). Their work should be appreciated because it explains how animals have been revealed in the Quran. Research into the animals is actually divided into three, namely 1) the animal symbolism in ancient times (pre-Islamic), 2) the animal symbolism of the Islamic era and 3) the animal symbolism of the present era. However, researchers have not touched the symbolism of sacred and profane animals in the Quran from the hermeneutic and structural anthropological perspective. Through the study of hermeneutics structural anthropology (Rahtika \& Rusmana 2013), the collective mediation revealed in the Quran can be found. Thus the researchers wanted to find out the meaning behind the text structure associated with the animals revealed in the Quran. In line with the views of Sims and Stephen about dismantling the related meaning/function within culture (Sims \& Stephen 2011:181), the researchers also wanted to uncover the collective mediation functions that are related to the animals revealed in the Quran. However, the study of the Quran collides with the sacred value. Because of this, someresearchers tend to avoid it. Starting from the phenomenon in this study, the researchers studied the Quran with a sense of reverence and sacredness.

This study aims 1) to describe animal patterns in the Quranic context concerning the anthropological structure of Claude Levi-Strauss, 2) to describe the patterns of collective animal mediation expressed in the Quranic context of the anthropological structure of Claude Levi-Strauss and 3) to describe the collective mediation function of animals in the Quran. The study of the Quran, referring to the thought and conceptualization of Saeed, should not be separated from the text, tradition, socio-historical context and flexibility present. Moreover, referring to the thoughts of Shahrour, the interpretation of the Quran is adaptable at all times, in all places and it has contextual meaning (Khusen 2012, Leaman 2006). The recitation of the text of the Quran must be intact (whole) (Qardawi 2001:1). Given the 
wholeness of the meaning of the Quran, the meanings that have emerged are the intact meaning. The wholeness is considered to be indispensable because there are a few studies that are fragmentary. The results of these studies seem 'false'. The fragmentation of the research was caused by the factor of distinct ideas and sects promoted by the researchers (Khuli \& Zayd 2005:80-81).

In relation to the integrity (wholeness) of the Quranic interpretation, Rahman explained that it can be properly obtained when adhering to the generality of the wording (al-ibrah bi umum al-lafalz) and the specification of pronunciations (al-ibrah bi khushush). Both of them are pronounced in order to produce a truly intact interpretation (Sibawaihi 2007:60061). The distinct ideas and sects can actually be reduced in order not to bring in a fragmentary interpretation. Thus the study of the Quran is not 'dry' and 'rigid'. Tafsir (Arabic) means that exposing and explaining the meaning of this paper is paired with the term 'hermeneutics' (hermeneuein: ancient Greek), which means interpreting.

The hermeneutic anthropological study in this research was paired with literary studies. In this case specifically, the study of the Quran has been adapted to the ideas of Abduh. He referred to the Quran as interpreted through a literary perspective. In the view of Abduh, according to Kuli and Zayd, a literary interpretation of the Quran went through the following stages. First, there is understanding the textual data of the Quran and interpreting it in general (universe). Second, there is interpreting the meaning of the Quran through stylistics. Third, there is understanding the context of historicity (Sibawaihi 2007). Fourth, there is reducing the context of historicity. The ideas of Muhammad Abduh were adapted to the context of the structural anthropological analysis of Claude Lévi-Strauss. To strengthen the analysis related to the animals, the Fabula concept of animals was used and raised by Eason who described animals (myth) around the world (Eason 2007). In addition to using the structural anthropological analysis of Claude Lévi-Strauss, the anthropological approach to the Islamic perspective was also used, namely the anthropology based on the ideas of Islamic leaders (Ahmed 1983:56-57). This is since the source of the data used in this study was the holy book of Quran. Thus the combination of structural anthropology and the anthropology of Islam makes an analysis of the Quran that is comprehensive and flexible.

Structural anthropology was developed by Claude Lévi-Strauss. This theory is used by anthropologists and folklorists to examine culture, folktales and the oral literature. Structural holistic anthropology in the study of folklore was recognized by Geertz (2002) and Morris (2005). Holistic theory appeared because Lévi-Strauss combined structuralism with anthropology. The combination of the two disciplines views the anthropological world; not a segment of it but the structure and anthropology itself both. In the view of Claude Lévi-Strauss, the concept of the theoretical and explanatory structure stated in the first example has nothing to do with the empirical reality. The structure does not directly exist in the notions held and it is behind what we observe. The structure cannot be observed but its products or causes can be observed (Lévi-Strauss 2001:4). The relationship envisaged by Claude Lévi-Strauss here is similar to that implied by Saussure between langue and parole (Strinati 2007). Lévi-Strauss argued that "music does not have words. There is nothing between the notes which can be called sometimes (like phonemes since they have no meaning of their own, but only consequence to reviews their combination) and the phrasing (however defined)". There can be no question that there is a musical equivalent of a dictionary. Music is not much different from linguistics because it has a structure. Lévi-Strauss's thinking about music and how it relates to linguistics cannot be separated from Saussure's thoughts about langue and parole, signifie and signifiant (Lévi-Strauss 1997:91). Such thoughts distinguish Lévi-Strauss from previous anthropologists.

Mite (Strauss called it a myth) from around the world has a 'resemblance' because it was built by a construction of the same mind. Lévi-Strauss (1963 \& 1969) stated that thought has a resemblance with Propp's thinking. He examined the story of Pari-pari in Russia from the structural perspective (Propp 1968). Therefore, the homology in folklore must be to different degrees. Therefore, LéviStrauss (1962:161) revealed that elements of universalization and particularization exist in folklore. The concept of a binary opposition in folklore is a universal mental reflection. Similarly, to mytheme and ceritheme, the anthropology structural analysis becomes more solid. The binary opposition concept could be related to life and death, men and women, top and down, left and right, cooked and raw and mediation (Dundes 2007:123), which functions and generates for society collectively. 
Mite, which has a homology within a socio-cultural context, is a community mediation intended to resolve the conflict (King \& Wilder 2003). People are looking for a solution to resolve the conflict in their socio-cultural context by channeling them into the story. The distribution is done in the form of anthropological unconsciousness. Therefore, they sometimes undertake meditation unconsciously. Thus the unstructured narratives could create mediations that have a function in their supporting community. In this context, the mediation can emerge through the logic of the story hidden in the structures of the story.

\section{Research Method}

The approach used in this study was a qualitative-narrative approach. A qualitative narrative uses data and descriptions that are narrated (Creswell 2007:37). The data used in this study was from the holy book of the Quran. The data used were the texts related and relevant to animals, both the context of the animal and/or stories of animals, whether real or unreal (symbolism). The data analysis techniques in this study were hybridized. First, there is reciting the verses (hermeneutical anthropological) in the Quran can be either universal or particular. Second, there is identifying the passages that relate to animals, whether real pets or unreal (symbolism). Third, there is the classification of the animals associated with the pattern of binary oppositions, referring to the Quran in the context of mytheme (unit of myths) and cheritheme (unit of stories) respectively. Fourth, there is the search for collective mediation functions for community supporters who are in the Quran, referring to both mytheme and cheriteme animals. Thus the analysis in this study relied more on hermeneutical anthropological analysis.

\section{Results and Discussion}

The term 'profane' in the context of anthropology or religion is opposed to the term 'profane'. Solemnity is actually linked to something considered hierophany. Suppose that at the time of animism, trees and rocks were considered sacred. Therefore, the tree and the stone were worshiped. However, the trees and the stones were not worshipped for themselves but instead for their hierophany (Elidae 1959:10-11). In Islamic thought, the very word used to describe the three sacred cities of Mecca, Medina and Jerusalem is the word haram. This means prohibited, which usually denotes food or behavior (Bennett 2002:199). For the holy places, they are also called the House of God (Butterlin 2015:64). Winzeler associated sacred animals with functionalist perspective, utilitarian and materialist interpretations through the opposition model: "animals are good to eat or not to eat, or to protect or to be protected" (Winzeler 2002:82). The term 'sacred' often emerges and it is used in the field of religion, such as the place, fashion, color, time, objects, animals, or plants usually related to the issue of ritual, namely the context of the relationship between humans and their God towards human transcendence.

Animals are important in religion. Therefore, in almost all religions, there is symbolism and stories about animals. Humans assume that an animal is important in religious terms because it is essential material in relation to holiness. In the detailed context, a sacred animal is able to protect humans from the calamity that will befall them. They 'reserve its use for activities that are of the greatest importance for the survival or otherwise protect people by preventing them from doing things they should not be doing (Winzeler 2002:82). Animals are important in religion, such as cows or goats. In relation to animal religious contexts, Watanabe (2016) states that animals are often related to religion, namely the lion, the bull and the mušhuššu-dragon. Animals in that religion are related to worship. Jensen (2017) shows that animals are a symbolism of God worshiped by humans. Therefore, in religion, animals are sacred but they can also be profane.

Humans and animals have a good relationship in relation to religion. Sacred animals in religion are used in sacrifice. There are two elements to the animals used in sacrifice. First, animals slaughtered on the orders of the Lord for the purification of the soul. Second, there are animals that refer to or indicate the presence of supernatural elements and the animal is being given to this element or presence (Recht 2015:5). In addition to functioning as sacrificial animals, the animals in the context of Islam are associated with kosher/halal, referring to the animals that are sacred and kosher (edible) 
for Muslims. The term halal refers to something that is edible. In relation to animals, kosher animals are the ones that are slaughtered in the name of Allah SWT. Allah SWT said: "Do not eat anything that is not the name of Allah upon it as such is ungodliness" (Depag 2011, Al-An'am [6]:121). The slaughter requirements should also be clear, namely regarding 1) the butcher, 2) the manner and purpose of the slaughter, 3) the body which should be slaughtered and 4) the tool used for the slaughter (Shihab 2007:143). Through the slaughtering process that is clear, the slaughtered animals become halal to eat. However, when the process of slaughtering animals is not in accordance with the procedures of Islam, the animal does not become halal.

Profane animals are the opposite of sacred animals. A sacred animal is considered to be an animal that is used in a ritual that is kosher, edible, and that brings good health and good luck to people. A profane animal does not. A profane animal is an animal that cannot be used in a religious ritual and it does not bring health, kindness and luck. In various religions in the world, sacred animals are opposed to profane animals. In relation to the symbolism, the animals raised in the holy book have meaning, both in terms of their surface structure and deep structure. In religion, the animal's symbolism is related to the exoteric or esoteric. Exoteric is related to the surface while esoteric meanings are related to the core meaning.

\section{Symbolism of sacred and profane animals in the Quran}

In the Quran, the verses that talk about animals are classified as follows. First, there are the animals that appear in the stories of the prophets. For this category, the animals are usually categorized in the terms of the stories of the animals in the Quran. Second, there are the animals that appear in the Quran that are associated with Islamic laws and/or animals related to people's daily lives. In this study, two categories for the animals are used in this research.

In the Quran, the researcher obtained the data on the following animals (universal and/or particular): donkeys (Depag 2011, Quran 2:259), crows (Depag 2011, Quran 5:31), sheep (Depag 2011, Quran 1:43), camels (Depag 2011, Quran 6:144), cows (Depag 2011, Quran 6:144), swine (Depag 2011, Quran 6:145), snakes (Depag 2011, Quran 7:107), locusts (Depag 2011, Quran 7:133), ticks (Depag 2011, Quran 7:133), frogs (Depag 2011, Quran 7:133), wolves (Depag 2011, Quran 12:13), birds (Depag 2011, Quran 12:36), reptiles (Depag 2011, Quran 11:56), bees (Depag 2011, Quran 16:68), mules (horse and donkey hybrid) (Depag 2011, Quran 16:8), dogs (Depag 2011, Quran 18:18), fish (satanic symbolism) (Depag 2011, Quran 18:61), snakes (The symbolism of Moses' stick) (Depag 2011, Quran 20:19), shepherd animals (Depag 2011, Quran 20:54), fish (Depag 2011, Quran 21:87), animal sacrifice (Depag 2011, Quran 22:34), ants (Depag 2011, Quran 27:18), hoopoe birds (Depag 2011, Quran 27:20), spiders (Depag 2011, Quran 29:41), termites (Depag 2011, Quran 34:14), ostriches (Depag 2011, Quran 36:49), horses (Depag 2011, Quran 7:133), elephants (Depag 2011, Quran 105:1) and the ulat (Depag 2011, Quran 105:5).

The appearance of animals in the Quran are those that have been exposed in the context of the verse. The animals raised in the context of sura (chapter) are The Cow (Al Baqarah), The Bee (An-Nahl), The Ants (An-Naml), The Spider (Al Ankabuut), The Chargers (Al'Aadiyaat) and The Elephant (Al Fill). Excessive data in this study was deliberately not raised because the required data has already been represented. Animals as the binary opposition in the Quran are divided into triadic types. First, there are the animals that are edible/kosher/for use in ceremony. The term 'kosher' refers to the root of the word/not bound, either as a hazard in the world or in the hereafter (Sihab 2007:148). The first type of animal is an animal that is uniquely or universally known by the Islamic community. Second, there are animals that are edible and kosher but not for use in ceremony. Third, there are animals that are not edible, that are unclean. In addition to the triadic concept of the animal categories, there are uncategorized animals, namely spiders, ants, elephants, caterpillars and termites.

\section{Pattern of triadic animals in the Quran}

The appearance of animals in the Quran in the anthropological view is not only based on a description but on their structure as well. Through these structures, patterns can be found, either dyadic, triadic, kwardic or pentadic. Based on the description of the animals revealed in the Quran, the triadic pattern 
of animals obtained in the Quran is categorized as follows. First, there are the animals that are included in this category that can be sacred, kosher and edible and that are used for sacrifice. This type of animal is an animal that can bring people to the point where there is a purification of the soul. This is not out of the story of the Prophet Ibrahim. Prophet Ibrahim once dreamed of being asked to slaughter his only son, Ismail. In such a position, the figure of the devil appeared and tried to influence Ibrahim. The devil explained that what was revealed to prophet Ibrahim was wrong. It was very unlikely that a father would have to slaughter his own son. The Prophet Ibrahim did not heed the deceit of the devil. He carried out the orders of Allah because the dream was a revelation. In the context of philosophy, what was done by the Prophet Ibrahim is a leap of faith. This means that they have a longer range than previously thought, namely relating to aesthetics and ethics. Slaughter in the name of God, sacrifice, was done by the Prophet Ibrahim although he was reluctant to do so. Because of his perseverance, Ismail was slaughtered after being suddenly transformed into a goat. This was the scenario of God. Since then, what is known by the Muslim community appears as Idul kurban. The feast is accompanied by the sacrificing of goats, sheep, cattle and camels.

The sacred animals are universally used by Muslims around the world as sacrificial animals. The sacrificial ritual performed by a Muslim has the following purposes: 1) to sacrifice what he loves to Allah as a form of love to Him, 2) to give the alms of the good animals (physical aspect) to others with the purpose of surrendering to Allah and to purify the soul from any sinful deeds. Through sacrificial animals, one expects that the reward is accepted by Allah SWT, and 3) in the pillars of the Hajj (for Muslims), a person shall slaughter sacrificial animals. If they can not slaughter sacrificial animals, they will be fined one sacrificial animal.

Second, there are animals that are edible, kosher and not used for sacrifice. Animals in the second rank are animals that are edible that are not suitable for ritual or sacrifice. This type of universal animal includes cattle (Depag 2011, Quran Thaahaa 20:54). There are also shepherd animals (Depag 2011, Quran Thaahaa 20:54), fish (of a certain type) (Depag 2011, Quran Al Anbiyaa' 21:87), bees, birds (Hud-hud, camels) and grasshoppers. Saying the name of Allah (Depag 2011, Depag 2011, Quran Al-An'am 6:118) before slaughtering these animals makes people able to eat the meat. Additionally, the carcasses of dead animals may be eaten so long as they live in water. For example, fish (Depag 2011, Quran Al-Maidah 5:96).

Third, the animals in the third rank are the animals that cannot be eaten and that are unclean. These animals are forbidden to eat (by Muslims). The third type of animal refers to a carcass, blood and pork (Depag 2011, Depag 2011, Quran An-Nahl 16:115) because it is dirty/unclean (Depag 2011, Quran Al-An'am 6:145). Animals that have become a carcass are an animal that should not be eaten because it has been slaughtered without saying the name of Allah SWT. It is thus considered to be dirty (unclean). The blood of animals that is also forbidden to eat is the blood of hoofed animals (Depag 2011, Quran Al-An'am 6:146) such as horses, mules (a hybrid of a horse and a donkey) and donkeys. In addition, sharp-hoofed animals are also forbidden to eat such as wolves, dogs, hawks and crows.

The triadic pattern contained in the animal world in the Quran represents the three areas of 1) kosher and for ceremonies, 2) kosher but not for ceremonies, and 3) not kosher. However, on the other hand, there are animals that are not included in the triadic category, referring to an uncategorized animal. This kind of animal is not explicitly mentioned in the Quran as a kosher animal, including whether it is for ceremonies, whether it is unclean or anything else. Some people express the view that if the animal does not have an obvious category, then it should be avoided (for consumption), thus hoping that we are safer from animals that fall into the category of 'lawful/unlawful but we do not know. In addition, animals that fall into the category 'lawful/unlawful' can actually be eaten with the condition that we do not have to eat it and there is no other food at the time.

The territory of animals that can be used for ceremonies and sacrifices or that cannot be used for sacrifice leads to the sacred (holy) world. The animals' territory leads to an area that may or not be eaten leading to the profane world. Both push and pull each other because each element has a respective region that is mutually reinforcing. Both of them pull each other back and forth because 
each element has its own mutually reinforcing territory. The sacred world will not stand firmly if there is no profane world. Both are mutually reinforcing and thus emerges a balance. The outlook in the context of Fromm (1973) and Wilson (1984) is called biophilia ethics and necrophilia ethics respectively. Both the constructive and deconstructive ethics are complementary and matchable so they bring harmony into life. Animal patterns are a dyadic manifestation. First, the animals that can be used in sacrificial ceremonies (kosher) are categorized as sacred animals. Second, the animals that cannot be used for sacrifice (unclean) are categorized as profane animals. The patterns of dyadic mediation animals contained in the Quran represent the animals selected for the sacred and profane worlds respectively. Therefore the animals used as ceremonies/sacrifices should be selected based on being of good quality in terms of their physical (not disabled, sick, and lean) and psychological (not crazy) natures. In addition, saying the name of God must be done before any slaughter. This sacred animal category is loved more by the supporting community. To go to the profane world, it is in contrast to the animals used for ceremonies/sacrifices. Therefore a profane animal category is considered to be filthy, disgusting and it is hated and disliked by the supporting community. The distribution of sacred and profane animals in the Quran shows that in a religious context, trust should be placed in the sacred and profane animals. This view is in line with Gore-Jones (2015), who classifies animals in religion into two, namely sacred and impure. Up until now, Muslims still hold fast regarding the sacredity of animals, especially the animals used in religious ceremonies (DahlanTaylor 2016). Thus the animals that are sacred in religion will be retained as sacred animals, while profane animals will remain profane animals in a religious context.

In addition to a pattern of dyadic mediation concerning the animals that lead to lawful and unlawful, a pattern of dyadic and invisible animals also appears in the Quran. An invisible animal in the Quran is manifested in the form of a dyadic pattern. First, there is an invisible animal that has helped people/ prophets. In this case, the invisible animal is categorized as a miracle. Second, there is an invisible animal that has deluded people/prophets. In this case, the invisible animal is categorized as a devil/ demonic incarnate. On the one hand, an invisible animal is an animal that helps people/prophets in the context of enforcing the Islamic religion. This picture is reflected in the story of the Prophet Musa when he faced Pharaoh. He threw down his walking stick and it became a big snake. The snake then ate all of the small snakes created by the witch as the small snakes created by the witch were the devil/demonic incarnate- these are represented by Pharaoh's men (Depag 2011, Quran 7:107 \& 117). In addition, pets like locusts, frogs and lice were the miracles of the Prophet Musa as as they were raised to punish his people who reneged on Allah Swt. Similarly, the Prophet Jesus brought the bird from the ground (Depag 2011, Quran 3:49). He also revived a dead bird (Depag 2011, Quran 2:260). The animal was categorized as invisible because it included a miracle that was given by Allah to His prophets as proof that the prophet Jesus was indeed a prophet (Mu'nis 2009). The invisible animal that deluded people was the demonic incarnate fish that appeared when the Prophet Musa sailed across the ocean (Depag 2011, Quran 18:61-65).

Prophet Sulaiman had a gift that enabled him to speak in the animal language. Therefore the Prophet Sulaiman could speak with the hoopoe birds (Depag 2011, Quran 27:20) and he was also able to hear the ants talking (Depag 2011, Quran 27:18). However, these animals were not categorized as invisible animals because these animals are the usual animals and so they were able to communicate with the Prophet Sulaiman. In addition, the story of a donkey that could live again after it had died did so for a hundred years and it was revived by Allah. Therefore, it was not categorized as an invisible animal. Lévi-Strauss's view of the universality in the world of anthropology essentially represents the unity of the collective mediation and so do animals in the Quran. These animals are the symbolism of the world of collective mediation. Therefore, in view of Lévi-Strauss, a researcher must be able to dismantle the collective representations contained in the symbolism so then the collective mediation can be found for the supporting community. The collective mediation is universal and particular. The term of the collective mediation function in anthropology is essentially linked with the function of 'something' and to the people who support or believe in 'something'. In this case, the animal symbolism in the Quran has a function in the supporting society of Muslims. 
The collective mediation functions of animal symbolism contained in the Quran are as follows. First, there are the animals that act as an intermediary for the holy man through sacrifice. In the Quran, the function of animals as an intermediary to be the holy man appeared in the story of the Prophet Ibrahim who slaughtered Ismail, and then the Prophet Ismail was replaced with a goat. This event made the Prophet Ibrahim a holy servant because he was willing to sacrifice his most beloved thing to Allah. Although plagued by demons, the Prophet Ibrahim stuck to his stance of sacrificing his son as a form of sanctity.

Second, there is animals as medicine/health for humans and so animals as a human helper, In the Quran, Allah said "And the God has inspired the bee, saying Make thou houses in the hills and in the trees and in the trellises wich the build" (Depag 2011, QS. An-Nahl:69) and "Then eat every kind of fruit, and follow the ways of the God that have been made easy for thee. There comes forth from the bellies a drink of varying hues. There in is the cure for me. Surely, in that is a sign for a people who reflect" (Depag 2011, QS. An-Nahl:70). Through the honey created by bees, humans become healthy after they consume it. Honey has become a medicine used to increase one's health and stamina. People like honey better than chemical medicines because it is natural and immediately produced by nature. In the modern context, animals have been used as assistant animals for human therapy, which is known as animal-assisted therapy (AAT). The animals that are used to help improve a person's mental development include dogs, cats, rabbits, horses, birds, guinea pigs and dolphins (De Mello 2012).

Third, there are animals as a human helper/prophet. In the Quran, raised animals actually help people to achieve their goals or they help humans during confusion. In Surah Al-Maidah: 32, "Then Allah sent a raven roomates scratched in the ground, that He Might show him how to hide the corpse of his brother. He said, "Woe is me! Am I not Able to be even like this raven so that I may hide the corpse my brother?" And then he became regretful" (Depag 2011).

Through the raven birds, Allah gave guidance. He helped Cain who killed Abel, his brother. Cain was confused to see the corpse of Abel. Then Allah raised the raven bird that was digging the ground. It was a symbol that Cain was given a sign to bury his brother. In the story of the Prophet Sulaiman, there was a bird that became an informant. The bird was named Hud-hud (a type of woodpecker). He was seeking information about things that were inside or outside of the kingdom of the Prophet Sulaiman. It appears in QS. An Naml: 22 "And not much later (came Hoopoe), then he said, "I know something that you have not known before and I brought thee out of the land of Saba believed an important news."”

The pattern of humans if they are connected and associated with animals will dyadically manifest. First, there are sacred-categorized human beings. Sacred humans essentially are under the command of Allah. Second, there are profane-categorized human beings. Profane humans essentially leave the love of Allah. People who have a way of life where they follow the orders of Allah consume kosher animals which will lead them to be sacred men (holy). The sanctity of humans will get stronger when they slaughter the sacrificial animals. In this context, the term refers to the story of the sacrifice of the Prophet Ibrahim who was asked to slaughter his son, the Prophet Ismail. The Prophet Ibrahim's belief was stronger when he determined whether to slaughter his son or not. This is called sacred. We provide our most beloved thing for ritual / sacrifice. This is done to show our love to Allah SWT. This type of human is a human who loves God as his lover. Therefore to become a truly sacred human being, one must eat kosher animals and perform ritual/sacrifice. In the context of the macrocosm, human beings need to find something that is kosher that they are willing to sacrifice to get to the heavenly world. A man who heads the transcendental world is not a man heading the immanent world. Profane-type men are the men eating unclean animals. They are the kind of people who do not carry out the command of Allah. Their closeness to the Lord (Rabb) becomes far because they are away from God. In addition, they also do not perform the ceremony/sacrifice that is needed to get close to Allah SWT. Therefore this type of man is far from the paradise of Allah and he is also hated by Him. These are the human beings who will be the dwellers of hell. Both sacred and profane are present in the mortal world that will lead men to the hereafter. Therefore they will mix and match each other. 


\section{Conclusion}

Based on the exposure to the symbolism of sacred and profane animals in the Quran in advance, this results in three findings. First, the Quran as the Muslims' holy book has an incredible substance of science that needs to be deeply and comprehensively explored. The study of the symbolism of sacred animals in the Quran shows that the Quran also speaks about the typology and function of animals. In the Quran, the symbolism of animals is not something ordinary. It is something extraordinary as well. If viewed comparatively, the religions that have emerged in the world also speak of the symbolism of animals with different degrees of similarity. Second, the pattern of animals in the Quran appears triadic according to the type of animal (edible/kosher/for the ceremony, edible/kosher not for the ceremony and unlawful). Dyadic refers to the type of animal that is mediated to become sacred-profane as well as for the types of invisible animal. Second, there is a pattern of collective mediation within the supporting community that is found where the animals in the Quran mediate human beings in the sacred-profane world. All of the ways that are open are related to a point of balance. It manifests that Islamic human beings can choose either way, the first or the second. When humans choose the first way, they become sacred. When humans choose the second way, they become profane. Both ways bring balance as Allah creates both sacred and profane men. Therefore Allah creates a haven for sacred human beings and hell for profane human beings. That is the justice created by Allah. However, humans can move from the profane to the sacred world and vise versa. Third, the animal symbolism that is manifested in the Quran shows that animals in the Quran have collective mediation functions to support the community. The mediation functions essentially refer to the function of animal symbolism in the Quran used to support the community, namely Muslims. The functions of collective mediation are as follows: 1) animals as intermediaries towards the holy man through sacrifice, 2) animals as medicine/health for humans and 3) animals as human helpers.

\section{References}

Ahmed AS (1983) Islamic Anthropology. Baghdad: Saudi Publishing.

Bennett C (2002) In Search of the Sacred: Anthropology and the Study of Religions. New York: Cassell.

Bahjat A (1982) Animals in the Glorious of Quran. [Accessed 22 February 2019]. http//www. islamicbasic.com.

Butterlin P (2015) Late Chalcolithic Mesopotamia: Towards a Definition of Sacred Space and Its Evolution. East. In: N Laneri (ed). Defining the Sacred: Approaches to the Archaeology of Religion in the Near. Philadelphia: Oxbow Books.

Birruni T (2012) Kisah Binatang Terbaik dalam Al-Quran. Yogyakarta: Qultum Media.

Creswell JW (2007) Qualitative Inquiry and Research Design: Choosing Five Among Approaches. London: Sage.

Dahlan-Taylor M (2016) Beyond barbarity and concealment: Animal sacrifice and religious slaughter in Islamic responses to postdomesticity. Culture and Religion, 17 (3):352-365. https://doi.or $\mathrm{g} / 10.1080 / 14755610.2016 .1216456$.

De Mello M (2012) Animals and Society: An Introduction to Human-Animal Studies. New York: Columbia University Press.

Depag (2011) Quran dan Terjemahan. Jakarta: Media Plus.

Dundes A (2003) Fables of the Ancients? Folklore in the Quran. Oxford: Roman \& Littlefield Publishers.

Dundes A (2007) Meaning of Folklore. USA: Utah State University.

Eason C (2007) Fabulous Creatures, Mythical Monsters, and Animal Power Symbols: A Handbook. London: Greenwood.

Elidae M (1959) Sacred and Profane: The Nature of Religion. New York: Harvest Books. 
Foltz RD (2006) Animals in Islamic. England: Oxford.

Fromm E (1973) The Anatomy of Human Destructiveness. New York: Holt, Rinehart and Winston.

Geertz C (2002) Hayat dan Karya: Antropolog Sebagai Penulis dan Pengarang. Yogyakarta: LkiS.

Gore-Jones L (2015) Animals, humans, angels and God: Animal symbolism in the historiography of the 'Animal Apocalypse' of 1 Enoch. Journal for the Study of the Pseudepigrapha, 24:268287. https://doi.org/10.1177/0951820715590547.

Hassan A \& Sadek S (2015) Animals symbolism in India American poetry. European Scientific Journal 11:61-81.

Hassig D (1995) Medieval Bestiaries: Text, Image, Ideology. New York: Cambridge University Press. Hidayat D (2010) Binatang dalam Al-quran: Tafsir Mawdhû’iy. Thesis, UIN Kalijaga, Yogyakarta.

Jensen HJ (2017) Aniconic propaganda in the Hebrew Bible, or: The possible birth of religious seriousness. Religion, 47 (3):399-407. https://doi.org/10.1080/0048721X.2017.1295827.

Khuli A \& Zayd NH (2005). Metode Tafsir Kesastraan atas Al-Quran. Yogyakarta: Binamedia.

Khusen M (2012) From Shari'a A'yniyya to Shari'a Hududiiya: Shahrour's Interpretation on Qur'anic Legal Verses. Al-Jamiah 50:431-459.

King VT \& Wilder WD (2003) The Modern Anthropology of South-East Asia. London: Routledge.

Kitchell KF (2013) Animals in the Ancient World: From A to Z. New York: Routledge.

Leaman O (ed) (2006) The Quran Encyclopedia. London: Routledge.

Lévi-Strauss C (1962) Savage Mind. London: Nicholson Ltd.

Lévi-Strauss C (1997) Look, Listen, and Read. New York: Basic Books.

Lévi-Strauss C (1963) Structural Anthropology. New York: Basic Books.

Lévi-Strauss C (1969) The Elementary Structures of Kinship. Toronto: Beacon Press.

Lévi-Strauss C (2001) Myth and Meaning. New York: Routledge.

Morris B (2005) Religion and Anthropology: A Critical Introduction. Cambridge: Cambridge University Press.

Mu'nis MH (2009) Memahami Islam melalui 20 Ayat Quran. Yogyakarta: Mizania.

Petropoulou MZ (2008) Animal Sacrifice in Ancient Greek, Judaism, and Christianity, 100 BC to AD 200. New York: Oxford.

Propp V (1968) Morphology of the Folktale. Austin: University of Texas Press.

Qardawi Y (2001) Approach the Quran. Cairo: Al-Falah Foundation.

Rahman A (2007) Ensiklopediana Ilmu dalam Al-Quran. Bandung: Mizania.

Rahtika Y \& Rusmana D (2013). Metodologi Tafsir Al-Quran: Strukturalisme, Semantik, Semiotik, dan Hermeneutik. Bandung: Pustaka Setia.

Recht L (2015) Identifying Sacrifice in Bronze Age Near Eastern Iconography. In: N Laneri (ed). Defining the Sacred: Approaches to the Archaeology of Religion in the Near East. Philadelphia: Oxbow Books.

Saeed A (2006) Interpreting Quran. Routledge: New York.

Sibawaihi (2007) Hermeneutika Quran (Fazlur Rahman). Yogyakarta: Jalasutra.

Sims M \& Stephen M (2011) Living Folklore. USA: Utah State University.

Schaefer DO (2015) Do animals have religion? Interdisciplinary perspectives on religion and embodiment. Anthrozoös 25:173-189. https://doi.org/10.2752/175303712X13353430377291.

Skrobonja A, Kontosic I, Bacic J, Vucevac-Bajt V, Muzur A \& Golubovic V (2001) Domestic animals as symbols and attributes in christian Iconography: Some example from Croatian sacral art. Vet. Med.-Czech, 46 (4):101-107. https://www.agriculturejournals.cz/publicFiles/140926.pdf. 
Shihab Q (2007) Wawasan Al-Quran: Tafsir Maudhû'i atas Pelbagai Persoalan Umat. Yogyakarta: Mizan.

Strinati D (2007) Popular Cultural. Terjemahan. Yogyakarta: Jejak.

Tlili S (2012) Animals in the Quran. New York: Cambridge.

Watanabe CE (2016) The symbolic role of animals in Babylon: A contextual approach to the lion, the bull and the mušhuššu. Iraq (77):215-224. https://doi.org/10.1017/irq.2015.17.

Worcester J (2017) The Animals of the Bible and Their Correspondences. South Yarra: Trieste Publishing.

Wilson EO (1984) Biophilia: The Human Bond with Other Species. London: Harvard University.

Yahya H (2003) True Wisdom Described in the Quran. New Delhi: Goodworld Books. 